\title{
Public Space, Public Discourse, and Public Libraries
}

\author{
By \\ Colleen Alstad \\ \& \\ Ann Curry
}

\section{Bio Statements}

\section{Colleen Alstad}

Email: coljohn@islandnet.com

Colleen is a part-time teacher-librarian, a student librarian in both an academic and a public library, and an MLIS candidate at the University of British Columbia. She ardently supports intellectual freedom, cultural heterogeneity, and an activist role for librarians

\section{Dr. Ann Curry}

Email: ann.curry@ubc.ca

Ann was a reference librarian and administrator in Canadian and Australian public libraries from 1972 to 1988. She is now an associate professor at the UBC School of Library, Archival and Information Studies, teaching research methods, collection management, library architecture, and a special course on intellectual freedom and censorship.

\section{Public Space, Public Discourse, and Public Libraries}

\begin{abstract}
The traditional mission of the public library-supporting the self-education of the citizenry in order that they may become fully participating members in a democratic society-has been devalued of late in favour of popularizing the library to attract more users. This shift has led to an emphasis on entertainment and marketing, and an abandonment of what many feel is the true purpose of a library. Loss of democratic tradition has simultaneously occurred on another front: civic space which allows for public assembly and discourse has disappeared or been downgraded into places for leisure and recreation rather than politics, with a concomitant decline in the quality of public discourse as citizens increasingly depend on profit-driven mass media for their "opinions." This paper contends that the public library is an ideal physical and psychological space for public discourse. By supporting public discourse, the public library can begin to reinvigorate both the quality of public discourse and its traditional commitment to democratic ideals.
\end{abstract}




\section{Introduction}

Most library professionals feel the tug of two fundamentally different approaches to public librarianship. One is based on the marketing principles of the private sector, and the other adheres to the traditional concept of the public library as a community record, storehouse of knowledge, and cornerstone of democracy. Examination of public library mission statements confirms that, while most libraries function somewhere in between these two extremes, few agree on the precise purpose of the public library.

Typically, mission statements mention the friendly and responsive environments of their libraries, the easy access to information, their support of recreational, educational, and cultural needs of their users and community. They sound pleasant, positive, and service-oriented. However, most exclude any reference to the traditional goal of the public library: a commitment to advancing democracy through an informed citizenry. This omission contradicts the expressed wish of many library organizations and professionals to revive the democratic ideal. Nancy Kranich, 2001-02 American Library Association (ALA) president, chose as her theme for the year "Libraries \& Democracy: The Cornerstones of Liberty" and published a book with the same title. At the 2001 Canadian Library Association (CLA) conference, former cabinet minister Lloyd Axworthy delivered his keynote address on "Public Space, Public Good, Public Purpose," in which he stressed the public library's importance to a "thriving community and working democracy" (Axworthy 2001). The title of IFLA's 2002 conference was "Libraries for Life: Democracy, Diversity, and Delivery." Clearly, many continue to regard the public library as a pillar of democracy even though this purpose is not reflected in the majority of mission statements.

Another forum for free expression of ideas—urban public space-has had its democratic nature challenged by the steady encroachment of private interests in formerly public arenas and by the desire of the public for controlled and secure spaces. Staeheli defines public space as "a setting for debate, the exercise of rights as citizens, and a place where people of diverse backgrounds can meet as a community" (Staeheli and Thompson 1997). True public space also has a high degree of user control and is unmitigated by corporate or government interference. The decline of public space can be traced to such worldwide trends as government downsizing, growth of corporate power, and the information and communication technology revolution. Financially strapped cities cannot afford to maintain public amenities such as parks, and come to depend on the private sector to fill the gap. Corporate plazas and shopping malls are ostensibly public spaces, yet they belong to the private realm. Owners have the right to exclude certain members of the public. People are welcome as long as they are working, shopping, or eating there, but use of this type of space is not a right, but a privilege. The requirement that these spaces be both 
profitable and safe has led to a demand for total management and controlled behaviour, which precludes political activity and undermines the public dimension of the space (Madanipour 1999). It also alienates and discourages a sense of belonging and community for large segments of society. Our increasing preference for privacy and security "diminishes social interaction and diversity, if only because strangers of differing ages, classes, ethnicities, genders, and religions have less opportunity to mingle in the same physical space" (Leckie and Hopkins 2002).

The loss of civic space and the resultant lack of unmediated social interaction is damaging to a democracy. How can we develop tolerance and acceptance of difference in an increasingly diverse society without provision of space for democratic intermingling? How will the public intellectual realm be sustained and developed if there are no physical spaces to support it? These are critical issues in an age of rapid changes in electronic communication, powerful pressures towards consumer individualism, and increasing disparities in wealth and access to information (Greenhalgh and Worpole 1995).

Hearing the opinions of others, listening to well-informed, articulate speakers on various social and political issues, airing our own views in a public forum ... this face-to-face interaction forces us not only to take responsibility for our opinions, but to adhere to standards of civil behaviour. By participating fully in these activities, we prepare our minds to make informed choices about who we elect, what we support, and how we contribute to public deliberation. "Public life is produced and reproduced by social practices that transpire in specific places_public places-and the library is certainly one of those enduring and successful public places" (Leckie and Hopkins 2002). It has special meaning to its users, who hold "a deep sense of place attachment: such places are part of their community, part of their social and cultural fabric" (Leckie and Hopkins 2002). Libraries provide safe space for unfettered public dialogue; they "disseminate information so the public can participate in the processes of governance ... they serve as gathering places for the community to share interests and concerns ... Ultimately, discourse among informed citizens assures civil society. ... [L]ibraries ensure the freedom to read, to view, speak, and to participate" (Kranich 2001).

Public discourse can enrich rather than simply distract us from life. As governments shirk their democratic responsibility to provide the spaces that make a true public realm and as changes in technology and information delivery both fragment the public realm and limit public discourse, public libraries-equitable, accessible, positive, nurturing — can step in to provide the place for community interaction that thinking people yearn for. A commitment by public libraries to serve this essential aspect of democratic life will necessitate an activist, rather than neutral, political stance and a rethinking of the library's mission. 


\section{Citizenship and "The Public" in Public Space}

An effective democracy is rooted in good citizenship. Citizenship entitles one to participate in public affairs and decide the fate of the community, and it presumes access to the public arena where these political and social issues are discussed and resolved (Staeheli and Thompson 1997). In ancient Greek society, politics was concerned not just with administration but "with educating the citizen as a public being who developed the competence to act in the public interest" (Bookchin 1987). Citizenship required a creative integration of the individual into his environment, demanding a critical mind and a strong sense of duty. The Athenians believed that excellence in public life was as crucial to one's character development as excellence in private life, and a citizen should be an asset to his society, his community, and his family and friends (Always "his," unfortunately; Athenian citizenship excluded women.) (Bookchin 1987).

Contrast the ancient Greek ideal with another (extreme) modern day version. Mike Davis, in City of Quartz-a frightening (and perhaps accurate) vision of modern day Los Angeles - describes the L.A. Police Department's perception of citizenship: good citizens are off the streets, "enclaved in their high-security private consumption spheres"; bad citizens are on the streets and therefore not engaged in legitimate business (Davis 1992).

However, on the streets, in public, was precisely where Athenians turned citizenship from an abstract ideal into an everyday living practice. The agora-"gathering place"-was the physical space where this practice occurred. Athenians assembled to mutually educate each other and expand their civic ideals of right and wrong. Emphasis on direct contact, full participation, and delight in variety and diversity, enabled this gestation of education, ethics, and politics (Bookchin 1987).

In modern-day North America, however, current municipal policy seems intent on prohibiting traditional civic activity. In L.A., it aims to "ensure a seamless continuum of middle-class work, consumption, and recreation" and "eliminate [the] democratic admixture on the pavements and in the parks" (Davis 1992). In Berkeley, public space has been "jeopardized by countervailing social, political, and economic trends" (Mitchell 1995). Planners create spaces for recreation rather than politics, and discursive political interaction has been "effectively banned." All that's left are the dead public spaces of office tower plazas and spaces with a "festive" theme promoting entertainment and consumption. Mitchell succinctly defines the two opposing visions of public space: one, a politicized space marked by free interaction and absence of coercion by powerful institutions; the other, a planned, orderly open space for recreation and entertainment, subject to usage by an appropriately-behaved public (Mitchell 1995). Modern-day 
public spaces are no longer places of assembly and debate; they have ceased to function as forums for political interaction. The purpose of public spaces, like the mission of the public library, has shifted from politics to entertainment and commerce.

Habermas conceptualized two separate worlds in modern society and hypothesized that the system-based on the demands of material production-increasingly interferes with and distorts the communicative activity in which the pursuit of knowledge and ethical understanding takes place (the lifeworld) (Braaten 1991). His theory is borne out as public sphere activities are banned from commercialized public spaces. In shopping malls, any sign of political activity-passing out leaflets, political discussions and speeches, voter registration - can lead to the eviction of the people involved. Legal challenges to these actions of mall owners have rarely been successful (Banerjee 2001).

Many so-called "public" spaces such as shopping malls challenge the definition of who constitutes "the public." These places are often contrived environments that "create an illusion of public space, from which the risks and uncertainties of everyday life are carefully edited out" (Banerjee). The "risks" may include people such as panhandlers, the urban poor, the homeless, youth, and non-conformists of various stripes. In People's Park in Berkeley, on "The Hill" in Boulder, in Los Angeles, in Vancouver, and in Manhattan's South Street Seaport, particular groups have been targeted for exclusion from a public space. These actions represented an attempt to redefine citizenship based on the moral requirement that members of these groups must participate appropriately and thereby "earn" their civic rights.

The struggle in People's Park has been between the university (who owned the land) and the park's homeless population. Since a student protest in 1969 , the park had functioned as a true public space, free from corporate or state control, and an important symbol of political power. Then, in 1991, the university decided to put volleyball courts in the Park to serve its students and other members of the public; unfortunately, the site they chose to convert into a recreational area was the traditional place for concerts and political organizing and the place where many homeless people slept. This central area, which included the Free Speech stage, was "a political space that encouraged unmediated interaction," a place where homeless people could make themselves visible and heard, could claim some public space, and therefore become a legitimate part of the public sphere. The Park "provided the space for representing the legitimacy of homeless people within 'the public"' (Mitchell 1995).

South Street Seaport in Manhattan, a privately-owned commercial space, tries to uphold the "publicness" of its former occupant, a museum, yet is purposefully exclusive. It keeps out the homeless population that occupies the nearby Bowery district partly by its design but primarily by the employ 
of a private police force. Although it is not stated explicitly that homeless people are not welcome, armed police are a sufficiently intimidating presence to keep them away (Defilippis 1997). In L.A., homeless people are denied not only a public space but also places to sit-identified by William Whyte as the most essential ingredient for a successful public space - public toilets, and even public drinking fountains (Davis 1992). Even restrictions on panhandlers redefine citizenship and the use of public space. Nathalie Des Rosiers points out the irony of Vancouver's panhandling bylaws "in a new-liberal state that emphasizes minimal interference in private financial transactions." The reason for these restrictions has to do with the privatizing of public space and the "moral anxieties over poor people's money, assuming that poor people spend money on alcohol, tobacco, and illegal drugs." By creating bylaws based on negative stereotypes, we are reinforcing "an exclusionary form of citizenship rooted in cultural concerns about public space" (Des Rosiers 2002).

Staeheli describes the extent to which the business community of "The Hill," a university district in Boulder, went to limit access to a group of "counterculture youth" after a particularly violent incident. Various groups tried to solve the problem without including the youth in their discussions. The merchants, she says, had wanted to capitalize on the bohemian atmosphere of the neighbourhood without having to face the bohemians. They attempted to delineate a part of the public space, i.e., the sidewalk, to which these youth would not have access and, in doing so, "attempted to create a new public to which countercultural groups do not belong" (Staeheli and Thompson 1997).

Denying access to public spaces "both renders invisible those that are not included and reinforces that invisibility by allowing those included to feel that they make up the entire public" (Defilippis 1997). This denial contributes to the increasing marginalization of the poor and the homeless, and alienates those people, such as political activists, who do not conform to the homogenized corporate ideal of consumers from within specific targeted lifestyles. Exclusion of particular groups is rooted in the assumption that they will behave in an illegal, threatening or otherwise inappropriate manner, thereby driving away customers and limiting opportunities for business.

Although we should be cautious about acting on the expectation of inappropriate conduct rather than actual bad behaviour, we must respect people's concern for their security. The presence of truly threatening individuals will limit public participation of the more vulnerable members of society such as women and the elderly. Paradoxically, their withdrawal weakens the community, diminishes quality of life, and strengthens the potential for disorder (Des Rosiers 2002). 
Kirsten Day discusses concerns women have with public spaces and suggests that the oft-criticized characteristics of privatized spaces like malls-with their emphasis on consumption, leisure, security, and controlled behaviour and design-may be considered as favourable when examining women's experiences. She illustrates how the qualities of a true public forum-universal access, democratic mixing among strangers, and free exchange of views and information-do not necessarily facilitate women's participation. Access is often limited by a woman's responsibilities for home and children. "Mixing" frequently means men are observers, women are observed; women are also discouraged from approaching strangers for safety reasons. And women may be pressured to moderate their views and behaviour to conform to a feminine ideal. Interestingly, of the top five "public" places where women said they felt comfortable, the only true public space was the public library (Day 1999). The commonly-held perception of the library as a safe and respectable place was confirmed by Leckie and Hopkins in their study of major libraries in Toronto and Vancouver. They found that "given the high volume and diversity of library users every day, it would appear that these two libraries are among the safest public places in their respective cities." This feeling of safety did not depend on the presence of security staff and surveillance cameras as much as on the patrons themselves: "the users are largely self-policing: they keep each other in check." The public library, therefore, qualifies as a "successful" public space (Leckie and Hopkins 2002).

\section{The Public Sphere and the Quality of Public Discourse}

The development of libraries has been central to the development of the public realm. Habermas' original conception of the public realm, or public sphere, as a "place" of rational public discussion on which democratic political development is based (Habermas 1989), derived from his study of the emergence of new democracies in Europe in the eighteenth and nineteenth centuries. In the twentieth century, however, the nature of the public sphere changed. New technologies in communication have had two significant effects. The first is the "virtualization" of the public sphere that is best exemplified by online discussion groups but also occurs on radio and television. The second is the manipulation of public discourse by mass media and its reconfiguration as an entertainment commodity.

\section{a) The Virtual Public Sphere}

Participation in public debate no longer requires access to a common physical space, and it is clear that the technology that facilitates remote communication changes the nature and content of discourse, and the value of information. Each new technology both limits and insists upon certain content and structures. The telegraph, for example, allowed us to talk to people on the other side of the continent even though, perhaps, we didn't 
really have anything to say. But just for the sake of using the new technology, we communicated anyway. Consequently, these communications-especially when a new technology is introduced-tend to be about incredibly trivial topics. One of the most damaging results of inventions such as the telegraph was the validity given to context-free information. The value of information used to be that it could lead to meaningful action (Postman 1985). Beginning with the telegraph and continuing with modern media, much of the information we receive-news stories about suicide in China, the love life of a Calgary millionaire, an E.coli death in New Brunswick, a lawsuit against a dead billionaire's family-is not directly connected with our lives. It gives us something to talk about, but it also makes us acutely aware of our own impotence in that it rarely leads to any meaningful action. The daily newspaper, Proust once observed, contains "all the misfortunes and cataclysms in the universe over the last twenty-four hours ... transformed for us, who don't even care, into a morning treat" (de Botton 1997). Information has become commodified, valued merely for its novelty and curiosity (Postman 1985).

While the Internet alters and limits our style of discourse, it has also expanded our range of communication. Many users have attempted to create genuine political forums using this technology. An illustrative example of public discourse via the Internet is "Minnesota E-Democracy," an online discussion list with over four hundred subscribers. Discussion is limited to state-based political issues and, unlike many online forums, contributors must observe certain standards of civility and rational debate. (For a discussion of another online forum —Slashdot-and an intelligent summary of Habermas' "public sphere" theory, see "Slashdot and the Public Sphere" at http://www.firstmonday.dk/issues/issue5 9/baoill/.)

In his study of online deliberation in general, Dahlberg used Habermas' conditions of the public sphere as a template and found that most online discussion did not meet these conditions. In brief, these conditions are:

- Autonomy from state and corporate control (commercial interests have colonized much of cyberspace)

- Reflexivity - participants must scrutinize their own moral and cultural assumptions (minimal in most discussions)

- Positions must be supported by reason rather than debate, and therefore open to exchange and critique

- Respectful listening and an attempt to understand the other's position (a general lack of this in many forums)

- Sincerity about identity and information (difficult to verify)

Discursive inclusion and equality (many forums exhibit exclusion based on social inequality; domination by certain individuals or groups)

Dahlberg concluded that Minnesota E-Democracy successfully met the first five conditions but, despite efforts to encourage diversity, it fell short for the last. Discussion tended to be dominated by well-educated, white males in 
the information professions. Their authoritative, adversarial style intimidated many women on the list whose contributions were often ignored, belittled, or silenced. Males generally did not have the patience to accommodate other styles of discourse. Some women fled to women-only discussion lists rather than put up with frequently uncivil behaviour (Dahlberg 2001). Although Minnesota E-Democracy has made great strides towards replicating the public sphere online, the traditionally powerful groups continue to dominate. Perhaps this particular group of users is well-versed in effective communication via this technology; hence, the technology itself may limit communication by limiting its democratic extent.

\section{b) The Mass Media and the "Dumbing Down" of Public Discourse}

Despite the limitations of the Internet for meaningful public deliberation, it appears to be wildly successful compared to what passes for public discourse on television. On daytime talk shows, guests reveal sordid personal experiences, ostensibly to reach some moral lesson but really just to titillate. In news reports and interviews, challenging questions are not asked, interpretations are not made, speakers are cut off from expanding on complex points. The media seems intent on exploiting the emotional aspect of a story - the anger, the blame, the tears, the happy ending -rather than exploring its intellectual content. In this way, the media contribute to deepening the tendency toward anti-intellectualism that, says Hafner, is omnipresent in North American life (Hafner and Sterling-Folker 1993). People are opting out of serious knowledge-seeking in favour of lightweight recreational information and entertainment. Habermas accuses the media industry of increasing profits by fostering this trend. Instead of guiding the public to an elevated culture and discourse, they are "adapting to the need for relaxation and entertainment on the part of the consumer strata with relatively little education" (Habermas 1989).

The media now value the speed of delivery of news more than its quality or utility. Television relies on fast-paced delivery and attention-getting images. The pace demands a reductive approach to complex issues and excludes discussion of consequences, moral questions, and interpretation. The detached and authoritative style of delivery implies that this is all there is to political debate, effectively eliminating communication (Postman 1985). To fill the vacuum left by the end of mass citizen participation in democratic discourse, people turn to convenient sources of information like talk radio shows where they are confronted by conservative hosts like Rush Limbaugh presenting simplistic interpretations of current events and instructing them how to think about complicated social and political issues.

By stressing currency, drama, and fast-paced presentation over relevance, the media has abdicated its social responsibility for elevating public discourse. They address people as spectators or victims rather than as citizens. Instead of suggesting ways society can act upon its problems, the 
media merely inform; instead of improving the climate for public discussion, the presentation in the media debases it (McCabe 2001) and creates mistrust and fear. It deprives us of the possibility of meaningful participation.

What was a public, Phelan says, has become an audience. In his early studies on communication and technology, and his more recent ones on cyberspace, Phelan noted that the public is deluded into thinking they are effective agents in the real world. Because we can move and change images on a screen, because we can "call in" to radio and television shows, we feel we are participating and interacting even though we are physically absent, alone and, "in any true political sense, impotent." We feel falsely empowered when, in fact, what we have just participated in is a poor substitute for a real social and political life (Phelan 1996).

Postman accuses television of having "made entertainment itself the natural format for the representation of all experience." TV does not allow people to be seen in the act of thinking, which alters the flow of discourse to the point where it is not discourse, only fragmented presentations. There is little time for reflection, analysis, rehashing, stops and starts or anything that is not scripted. Any news or debate is soon followed by a series of commercials that defuse its impact and render it banal. Such juxtapositions show no respect for the subject or for the intelligence of the viewer, and "do great danger to our sense of the world as a serious place." Television specializes in "information" that is superficial, irrelevant, fragmented and misleading which, Postman asserts, "creates the illusion of knowing but is in fact leading one away from knowing." This is the inevitable result of packaging news as entertainment. In addition to losing our capacity to think, and our social and political potency, we lose our sense of what it means to be knowledgeable and well-informed (Postman 1985).

\section{Does Anyone Care?}

Banerjee asks the obvious question: Is the typical consumer completely co-opted by the public life of themed experiences and places dedicated to consumption (Banerjee 2001)? And, one could add, by television's version of public participation? He answers that recent events, such as protests against the World Trade Organization (WTO) and International Monetary Fund (IMF) meetings, reflect frustration over powerlessness against global corporate interests and lack of local control. Indeed, the growth of community activism, revitalization by immigrant communities, development of neighbourhood councils as mandated recently in Los Angeles, and growth in neighbourhood-based nonprofit groups, may reflect the early stages of a movement to "reclaim the public realm at a community level" (Banerjee 2001). 
People crave public discussion and a sense of community. Some of this desire is reflected in the growth of discussion groups, salons, and philosophy cafes. Thoughtful people who worry about the fragmentation of contemporary life and the decline of meaningful activities that bring people together, are looking for social moorings, for real dialogue in real space (McCabe 2001). A sense of community is often what people cite as missing when responding to social ills. Civic dialogue helps to build community and strengthen democracy and the public library is an ideal place to encourage this activity.

\section{The Public Library as a Place for Public Discourse}

Crucial to democracy is civic participation in a viable public space, but individuals are not coming together to participate in social and political debate partly due to lack of a congenial space. Citizen involvement, therefore, is being taken over by professional politicians, further reducing civic life and replacing community with a climate of mistrust. Halbert recommends that citizenship "devolve" into face-to-face community building in order to re-establish mutual trust and withstand catastrophe. She encourages rebuilding of the public square, and reinvigorating the public sphere, or democracy will remain superficial (Halbert 2002).

Habermas' concept of the public sphere shares many attributes with public libraries such as equality, accessibility (its "indispensable ingredients"), and democratic control and participation. It is a realm in which individuals gather to participate in open discussion; no one enters into discourse with an advantage over another (Holub 1991). As a physical place, the public library exemplifies the public sphere.

Prominent people from Thomas Jefferson and Franklin D. Roosevelt to Oprah Winfrey ("Getting my library card was like citizenship.") have linked the library to citizenship and democracy (Kranich 2001). However, some librarians have a very different idea about the role of the public library. Consider the following mission statement from the public library in Aurora, Illinois:

The mission statement of the Library is to provide not only the best library services, material, staff, and cost-efficient facility but to aggressively market and promote our extensive reference collection, our adult and children's collections and provide a diverse, educational, cultural, and recreational resource through a variety of media to our community's changing age and demographic patterns, limited only by available funding and other resources supplied by residents and community organizations. 
The references to recreation, cost-efficiency, funding, and aggressive marketing, as well as the hard-sell tone, signify what McCabe calls a "libertarian" approach, a political term meaning emphasis on the radical autonomy of the individual. The libertarian public library "is a specialized, demand-based materials distribution service in the style of the private sector but with a public subsidy" (McCabe 2001). The 2001 Canadian Library Association national conference featured a session entitled "Marketing Public Library Services" in which the speaker discussed the importance of "discovering what library customers want," understanding that "our customers' interests [come] from learning what they buy and own," developing "strategy for marketing our products," and "our competitive edge." This is one sign that the libertarian approach is alive and well among library professionals.

Other, more typical, mission statements emphasize the importance of providing access to information in addition to supporting the educational, recreational, and leisure needs of the community. Arthur Hafner and Jennifer Sterling-Folker call this approach the "popularization movement" and criticize it for placing too much emphasis on entertainment and simple provision of information rather than actively encouraging unfettered public dialogue and disseminating information "so the public can participate in the processes of governance" (Kranich 2001). A public library, they argue, must "support and reinforce the democratic ideals of American society" (Hafner and Sterling-Folker 1993).

The reason that many librarians have rejected the original purpose of the library, according to Hafner, is rooted in the Public Library Inquiry of the 1950s. This inquiry uncovered a number of "inconvenient facts," among them, that only a minority of the population uses the library, mostly for entertainment such as popular fiction rather than serious enquiry.

Librarians, when faced with these statistics indicating that the library did not and could not match its idealistic democratic goals, began to believe that the library was no longer relevant to most people; at the same time, they were under pressure from municipal administrators to justify their funding in a tangible way, e.g., circulation and user statistics (Hafner and SterlingFolker 1993).

Libraries have responded by moving toward popularization in the belief that the more people who use it, the more important the library will be to the community, which will show its appreciation through a willingness to support the library with tax money. Hafner argues that this response by librarians misinterprets the behaviour of the public. Studies have indicated that a significant majority feel that the public library is "very important" to their community, regardless of whether they use it or not (Hafner and Sterling-Folker 1993). The public will willingly pay for the library because it symbolizes their highest societal ideals, such as provision of education not because the library has the latest John Grisham novel (McCabe 2001). 
It is not use, but availability for use, that characterizes universal, tax-paid forms of provision such as libraries (Greenhalgh and Worpole 1995).

Do we want to become just another "information and entertainment supplier"? asks Hafner. If so, why should we be publicly funded? By treating the library as if it were just another commercial enterprise, the popularization movement dismisses political, social, and moral values in favour of economics. The amorality of the marketplace, totally indifferent to the welfare of society, is an unlikely foundation for a social institution (McCabe 2001), whereas the democratic purpose provides the public library with a solid justification for continued community support.

Emphasis on the economic value of libraries undervalues or ignores their tremendous social value, which is usually excluded from assessments of library efficiency and economic value. Social impacts that are significant to the public sphere include the following:

- They are the entry point into the wider culture: libraries reflect the ideals of civil society and ensure that all citizens have access to the basic resources that allow them to enter a public sphere, to belong to their society. They combine the conceptual principle of the right to knowledge with the physical rights of access to a building - a public institution. They are inclusive and non-stigmatizing, with a low "entry threshold", i.e., you don't have to speak to anyone. The sense of openness and accessibility goes to the heart of the idea of a public sphere.

- A library is one of the few institutions that is regularly and uniformly open to children and young people. It provides youth with social and educational opportunities in a place that is neither school nor home. It allows them a presence in a place where they are neither threatened nor perceived as a threat.

- It gives access to news and information that helps to form public opinion, so essential to the public realm; it provides the means for individuals to take part in political and social debate.

- Unlike many public agencies in disadvantaged areas, the library is a positive place and supports positive activity and growth; other places may be symbols of deprivation and negativity (Greenhalgh and Worpole 1995).

- People can just sit quietly, read, and reflect, "without the pressure to act as consumers that is so pervasive in other sorts of spaces" (Leckie and Hopkins 2002).

- New immigrants often use the library to learn English; the library is a place where they can feel included and productive "in a way that would be almost impossible in other public spaces, such as cafes, parks, museums," etc. (Leckie and Hopkins 2002).

These positive social effects are not easily measured, however, as 
qualitative indicators are difficult to apply. Ironically, the qualities that make the library most appropriate for civic dialogue-inclusiveness, access to the wider culture, availability of information, a positive, non-stigmatizing atmosphere-are also the ones that are disregarded in formal assessments of library service.

\section{What Can Public Librarians Do?}

In the first decade of the twenty-first century, degradation of the public realm, whether it be physical or technological, continues to diminish public life, and loss of appropriate public spaces is leading to a further decline in civic engagement. Despite the best efforts of virtual communities, place-based communities are still important. As citizens continue to feel a vague sense of powerlessness and frustration, and what passes for public discourse becomes just another source of entertainment, the public library's fundamental democratic function is more important than ever. To support democracy and the public sphere, and to provide a forum for equitable and meaningful public discourse, public librarians should consider the following ideas:

\section{Re-examine the mission statement:}

Is a library just a materials distribution centre? Or, perhaps, an "information storehouse aggressively orchestrating the coexistence of all available technologies"? (Rem Koolhaas, Seattle Public Library architect) We can continue to provide for the recreational needs of users without forfeiting our commitment to the democratic ideal. To demonstrate this commitment, librarians need to adopt a more activist stance that should be reflected in the mission statement. Replace verbs like "maintain," "provide," and "be" with "promote," "advocate," and "do."

One consideration is the adoption of the "commons" principle advocated by the Public Library Association. Over forty U.S. public libraries have subscribed to this concept, which states that they will "address the needs of people to meet and interact with others in their community and to participate in public discourse about community issues" (Public Library Association 2001. At http://www.pla.org/conference/planning /responses.html). In her article "Citizenship, Pluralism, and Modern Public Space," Debora J. Halbert recommends redefining citizenship as "faceto-face community building" to defuse "us" versus "them" divisions (Halbert 2002). The PLA commons initiative supports her view.

\section{Promote the library as a public forum and tailor new education programs to the public forum concept:}

The 1948 recommendations of the ALA's National Plan for Library Service are still valid. They urge libraries to provide "lectures, forums, and 
discussion groups." Standards for public discussions could be based on Habermas' conditions for the public sphere as discussed earlier, or on Richard Rorty's qualities of reason: tolerance; respect for the opinions of those around one; willingness to listen; reliance on persuasion rather than force; avoidance of dogmatism, defensiveness, and righteous indignation (Watson 2000).

Some libraries create forums for specific groups. Halifax (Nova Scotia) Public Library holds a weekly Women's Group featuring "conversations, crafts, speakers and films on everyday issues affecting the lives of women" (www.halifax.library.ns.ca). This type of activity would facilitate inclusion of reluctant citizens in the public sphere.

Provide guidelines for patrons on issues such as acceptance of diversity, techniques for effective discussion, and the value of having informed opinions. Some of these lessons could be based on guidelines from philosophy cafés. For example:

- One must be open to having one's view questioned and explaining reasons for it.

- One must listen to what each person says and reflect on it.

- Civility goes hand in hand with reason. Dialogue does not involve combative argument. We do challenge each other's opinions, but the format is collaborative inquiry.

- All views are welcome.

(Adapted from http://www.philosophicalcounseling.com/cafe.htm)

\section{Be a great public space:}

The Project for Public Spaces has identified four key qualities in a successful public space. They are:

- It is accessible: is the entrance easy to see from the street? Is there a transit stop nearby? Is it accessible to people with special needs?

- People are engaged in activities: Do activities serve people of different ages? Is there a balance between men and women?

- It is comfortable and has a good image: Are there enough places to sit? Is it clean? Does it feel safe? Is the noise level appropriate to the setting?

- It is a sociable place: Is this a place where you would choose to meet friends? Does a mix of ages and ethnic groups that reflect the community at large come here?

\section{Be wary of discrimination in library policy:}

This discrimination can be covert or unintended but examples abound, especially with regard to the homeless. Some public libraries are effectively limiting access to homeless people by restricting the size of belongings 
patrons bring in (Seattle, Tacoma), or by prohibiting people with body odor because they are a "nuisance to patrons." (Broward County, FL). These are understandable concerns, but the library should attempt to work with other agencies so that, for example, homeless people have a safe place to leave their belongings. Also, library policy should not redefine "patron" to exclude homeless people; this is the same as the merchants of Boulder redefining the "public" to exclude a group that made them uncomfortable. Homeless people are patrons, and the public library is one of the few places to which they have rights of access. Staff and board member training may be required to ensure equitable access in practice and policy.

\section{Resist colonization by commercial interests:}

According to Hafner and McCabe, the public equates the library with its highest societal ideals-education, democracy, civic participation. These are concepts not comfortably associated with overt commercialization. Names of prominent corporate donors featured throughout the new San Francisco Public Library led one user to accuse the library of having "left its soul behind" (Ottawa Citizen, 8 May 2002). The move by the Vancouver Public Library to put corporate logos on library cards caused a local journalist to complain that "the library's long-term health-indeed its integrity as a public service-is being damaged" (Vancouver Sun, 3 January 1998). Others argued that "despite the civic commitment to knowledge, education," etc. ... "the implications that such a public service, fundamental to free thinking and democracy, is for sale is a deplorable sign of the times" (Vancouver Sun, 3 June 1995). The "ongoing ideological shift within libraries away from [a] neutral status as public institutions toward that of an active agent for private interests in the market economy" demonstrated by the presence of gift shops, cafes, and vending machines will "tarnish the sacred tenet upon which libraries have been founded" and threaten to transform their fundamental nature (Leckie and Hopkins 2002).

\section{Regard patrons as citizens:}

McCabe dismisses the notion that library users are customers; instead, he says, they are "co-owners of a democratic institution that is shared by everyone" (McCabe 2001). Supporting patrons' recreational "needs" with henna parties and such will entertain and distract them but will not substantially enrich their lives. And simply meeting their information needs does not go far enough. Citizenship is an ongoing process of educational, ethical, and political growth, and the rights and duties of a citizen are, in part, defined in terms of freedom of assembly. In ancient Athens, citizens assembled not just to formulate public policy, but to mutually educate one another in the ability to act justly and to expand their civic ideals of right and wrong (Bookchin 1987). We can encourage participation in civic dialogue by providing opportunities for people to meet face-to-face in the only public agency that guards against the tyrannies of ignorance and conformity (Hafner and Sterling-Folker 1993). Treating patrons as citizens 
implies providing not only access to information but also an arena for public deliberation, and it fulfills the library's mission "to work as an agent and partner within the community to promote the quality of society and the enrichment of the citizenry" (Hafner and Sterling-Folker 1993).

\section{Conclusion}

To combat the loss of public space and lack of civic engagement, we need to rebuild social infrastructure and re-establish the philosophical framework of public librarianship. One way to do this is to provide a forum for public discourse. A public library is free, non-judgmental, and safe. It is open evenings and weekends, centrally located, open to all ages, socioeconomic backgrounds, political and sexual orientations, and interests. It is a true public space and an ideal setting for expression of diverse opinions on political and social issues. It can function as a centre from which to rebuild community and trust, and a forum for civil and collaborative inquiry.

We need adequate civic space to maintain a civil society, says Barber. A place that "accommodates the mutuality of "you and me"' (Barber 1998) strengthens our social morality and, ultimately, our democracy. That place is the public library.

\section{Reference List}

Axworthy, Lloyd. "Public Space, Public Good, Public Purpose." Keynote address to the Canadian Library Association Annual Conference. Winnipeg, June 13 2001. Available at http://www.cla.ca/resources/cla2001 laxworthy.htm

Banerjee, Tridib. 2001. The Future of Public Space. Journal of the American Planning Association 67 (1): 9-24.

Barber, Benjamin. 1998. A Place for Us: How to Make Society Civil and Democracy Strong. New York: Hill and Wang.

Bookchin, Murray. 1987. The Rise of Urbanization and the Decline of Citizenship. San Francisco: Sierra Club Books.

Braaten, Jane. 1991. Habermas's Critical Theory of Society. Albany: State University of New York Press.

Dahlberg, Lincoln. 2001. Extending the Public Sphere through Cyberspace: The Case of Minnesota E-Democracy. First Monday 6 (3). Database online. Available from INSPEC, PAIS, Inform Scientific Abstracts.

Davis, Mike. 1992. City of Quartz: Excavating the Future in Los Angeles. 
New York: Vintage.

Day, Kristen. 1999. Introducing Gender to the Critique of Privatized Public Space. Journal of Urban Design 4 (2): 155-178.

De Botton, Alain. 1997. How Proust Can Change Your Life. New York: Pantheon.

Defilippis, James. 1997. From a Public Re-Creation to Private Recreation: The Transformation of Public Space in South Street Seaport. Journal of Urban Affairs 19 (4): 405-417.

Des Rosiers, Nathalie. 2002. Public Space, Democracy, and the Living Law. Plan Canada 42 (2): 22-24.

Greenhalgh, Liz and Ken Worpole. 1995. Libraries in a World of Cultural Change. With Charles Landry. London: UCL Press.

Habermas, Jurgen. 1989. The Structural Transformation of the Public Sphere: An Inquiry into a Category of Bourgeois Society. Cambridge, MA: MIT Press. Originally published in German in 1962.

Hafner, Arthur W. and Jennifer Sterling-Folker. 1993. Democratic Ideals and the American Public Library. In Democracy and the Public Library: Essays on Fundamental Issues, ed. Arthur W. Hafner, 9-43. Westport, CO: Greenwood Press.

Halbert, Debora J. 2002. Citizenship, Pluralism, and Modern Public Space. Innovation 15 (1): 33-42.

Holub, Robert C. 1991. Jurgen Habermas: Critic in the Public Sphere. London: Routledge.

Kranich, Nancy, ed. 2001. Libraries \& Democracy: The Cornerstones of Liberty. Chicago: American Library Association.

Leckie, Gloria J. and Jeffrey Hopkins. 2002. The Public Place of Central Libraries: Findings from Toronto and Vancouver. The Library Quarterly 72 (3): 326-372.

Madanipour, A. 1999. Why are the Design and Development of Public Squares Significant for Cities? Environment and Planning B: Planning and Design 26: 879-891.

McCabe, Ronald B. 2001. Civic Librarianship: Renewing the Social Mission of the Public Library. Lanham, MD: Scarecrow Press.

Mitchell, Don. 1995. The End of Public Space? People's Park, Definitions of the Public, and Democracy. Annals of the Association of American Geographers 85 (1): 108-133. 
Phelan, John M. 1996. CyberWalden: The Inner Face of Interface. In Communication and Cyberspace: Social Interaction in an Electronic Environment, ed. Lance Strate, Ronald Jacobson, and Stephanie B. Gibson, 39-48. Creskill, NJ: Hampton Press.

Postman, Neil. 1985. Amusing Ourselves to Death: Public Discourse in the Age of Show Business. New York: Viking.

Project for Public Spaces. 2001. What Makes a Successful Public Place? [website]; available from http://www.pps.org/topics/gps/gr place feat; Internet; accessed 2 March 2003.

Staeheli, Lynn A. and Albert Thompson. 1997. Citizenship, Community, and Struggles for Public Space. Professional Geographer 49 (1): 28-38.

Watson, Peter. 2000. A Terrible Beauty: The People and Ideas the Shaped the Modern Mind. London: Phoenix Press. 